\section{Ademir, A Myrobalan Rootstock for Plums}

\author{
M.A. Moreno, M.C. Tabuenca, and R. Cambra \\ Departamento de Pomología, Estación Experimental de Aula Dei (CSIC), \\ Apartado 202, 50080 Zaragoza, Spain
}

Additional index words. Prunus spp., propagation, compatibility

Ademir is a Myrobalan (Prunus cerasifera Ehrh.) rootstock developed at the Estación Experimental de Aula Dei, Zaragoza, Spain, for use as a rootstock for European plums and prunes ( $P$. domestica L.) (Cambra, 1990; Cambra and Cambra, 1973).

Ademir is graft-compatible with a wider range of plums than is Myrobalan B. It is easily propagated by hardwood cuttings. When treated with indolebutyric acid at 500 mg.liter ${ }^{-1}$, hardwood cuttings of Ademir and Myrobalan B had similar rooting percentages, $84 \%$ and $88 \%$, respectively.

Ademir maiden trees have an upright growth and a lower vigor than Myrobalan B and the mean of the other clones of Myrobalan included in the selection process (Cambra, 1990). Plants of Ademir were $15 \%$ smaller than those of Myrobalan B. Ademir would be suitable for plum cultivars to avoid excessive vigor or to increase planting density when tree size needs to be controlled.

Ademir adapts well to highly calcareous and compact soils, being resistant to iron chlorosis and root asphyxia. All nursery and orchard trials were performed on heavy clay and calcareous soils ( $\mathrm{pH}=8$ to 9 ) with a high content of total ( $30 \%$ to $35 \%)$ and active $(10 \%$ to $11 \%$ ) lime. In these soils, no symptoms of chlorosis have been observed for scions grafted on Ademir. Under waterlogging conditions, caused by flood irrigation and poorly drained soils, no trees on Ademir died.

\section{Origin}

Ademir, previously known as Myrobalan $599 \mathrm{AD}$, was selected in 1990 from openpollinated seedling populations of Myrobalan at the Estación Experimental de Aula Dei (Cambra, 1990; Cambra and Cambra, 1973). The clone was selected for good rooting abil-

Received for publication 14 Mar. 1995. Accepted for publication 10 Aug. 1995. Financial support was provided by Comisión Asesora de Investigación Científica y Técnica and Comisión Interministerial de Ciencia y Tecnología. M.A. Moreno was supported by Consejo Asesor de Investigación de la Diputación General de Aragón and Consejo Superior de Investigaciones Científicas. We thank A. Arbeloa and A.M. Casas for critical reading and translation of this manuscript. The cost of publishing this paper was defrayed in part by the payment of page charges. Under postal regulations, this paper therefore must be hereby marked advertisement solely to indicate this fact. ity, less vigor, excellent graft compatibility with plums, and better graft compatibility with apricot (Prunus armeniaca L.) cultivars than evident with Myrobalan B and Marianna rootstocks.

\section{Compatibility}

Ademir has shown good graft compatibility with European plum and prune cultivars, when tested in nursery or orchard trials (Table 1) according to the criteria of Herrero (1951) and Mosse (1960). Tests were usually made for the 3 to 4 years following grafting. With plum cultivars grafted on Myrobalan, Mosse (1960) found a good correlation between union structure of 1- and 2-year-old trees (Herrero, 1951) and in the similar set of 10-year-old trees. In addition, Mosse (1960) reported that union structure showed a general tendency to improve as the trees aged. In particular, Ademir has been tested with 'Reine Claude d'Oullins', 'Reine Claude Rose', 'Fraila Morada', and 'Martin' plums, because these cultivars and the 'Reine Claude' group, in general, are graft incompatible with Myrobalan B and other Myrobalan or Marianna selections frequently used as plum rootstocks (Cambra, 1990; Herrero, 1951; Mosse, 1960; Okie, 1987). Ademir has shown good graft compatibility with these cultivars. It is also graft-compatible with Japanese plum ( $P$. salicina Lindl.) cultivars, although the range of cultivars tested is not extensive (Table 1). observations were made 3 to 4 years after grafting.
The behavior of apricot cultivars grafted on Ademir differs with the cultivar. Ademir shows good graft compatibility with 'Paviot', a cultivar included by Crossa-Raynaud and Audergon (1987) within the group of apricot cultivars that are compatible with a wide range of rootstocks. Trials with Canino and Moniqui, apricot cultivars classified as difficult-to-graft noncongenial cultivars (Crossa-Raynaud and Audergon, 1987; Duquesne, 1969), showed that, although their compatibilities appear better than the compatibility of Myrobalan B and Marianna GF 8-1 (Cambra, 1979, 1990), they are not sufficient for commercial use.

\section{Description}

One-year-old shoots are purplish red-green in spring and summer and purplish-brown and green in winter. Internodes are similar in length to those of Myrobalan B. Leaves (Fig. 1) are larger than those of Myrobalan B; they have wavy dentate margins and are deeper green than Myrobalan B. Mean length : width ratio of the leaf blade is $1.65 \pm 0.10$, slightly lower than that of Myrobalan B (1.86 \pm 0.03$)$. Leaf petioles (1.4 cm long) are channeled and deep purple. Sometimes there is one gland at the base of the leaf blade. At the beginning of growth, leaves have small stipules. Leaf fall is late in the season, similar to that of Myrobalan B.

Flower budbreak takes place early in the season, with the Myrobalan group. Flowers are small, similar in size to those of Myrobalan $\mathrm{B}$, and smaller than those of $P$. domestic $\mathrm{L}$. or $P$. insititia L. plums. Flowers are white, with 25 to 30 stamens and one pistil. The stigma position is at the same level as the anthers or slightly below. The anthers are yellow just before dehiscence. Fruit are rounded, symmetric, and slightly smaller (7 to $9 \mathrm{~g}$ ) than those of Myrobalan B (10 to $12 \mathrm{~g}$ ). The skin is dark purplish-red, with a little skin bloom. The flesh is yellow-amber and reddish close to the skin. We consider the flesh to be juicy, sweet, and pleasant to eat. The stone is adherent, light

Table 1. Compatibility rating for several plum scion cultivars on Ademir and Myrobalan B rootstocks.

\begin{tabular}{lcccc}
\hline & \multicolumn{3}{c}{ Rootstock } \\
\cline { 2 - 5 } Cultivar & \multicolumn{2}{c}{ Ademir } & \multicolumn{2}{c}{ Myrobalan B } \\
\cline { 2 - 5 } \cline { 3 - 5 } No. trees & Compatibility & & No. trees & Compatibility $^{2}$ \\
Furopean plums & & & 10 & I \\
Martin & 10 & $\mathrm{C}$ & 98 & $\mathrm{I}$ \\
Reine Claude Althan & 126 & $\mathrm{C}$ & 15 & $\mathrm{I}$ \\
Reine Claude Oullins & 15 & $\mathrm{C}$ & 30 & $\mathrm{I}$ \\
Reine Claude Rose & 72 & $\mathrm{C}$ & 10 & $\mathrm{I}$ \\
Stanley & 10 & $\mathrm{C}$ & 5 & $\mathrm{~B}$ \\
D'Ente GF 707 & 15 & $\mathrm{C}$ & 8 & $\mathrm{C}$ \\
President & 15 & $\mathrm{C}$ & 6 & $\mathrm{C}$ \\
Reine Claude Bavay & 10 & $\mathrm{C}$ & 20 & $\mathrm{C}$ \\
R.C.T. Chambourcy & 15 & $\mathrm{C}$ & 20 & $\mathrm{C}$ \\
Japanese plums & 20 & $\mathrm{C}$ & & $\mathrm{C}$ \\
Delbarazur & & & 26 & $\mathrm{C}$ \\
Friar & 22 & $\mathrm{C}$ & 20 & $\mathrm{C}$ \\
Golden Japan & 15 & $\mathrm{C}$ & 24 & $\mathrm{C}$ \\
Santa Rosa & 10 & $\mathrm{C}$ & 31 & $\mathrm{C}$ \\
\hline
\end{tabular}

${ }^{2} \mathrm{C}=$ compatible, normal trees, continuous bark and wood in the union; $\mathrm{B}=$ broken trees at the graft-union in the nursery; I = localized incompatibility, cambial or vascular discontinuity in the union. Most 


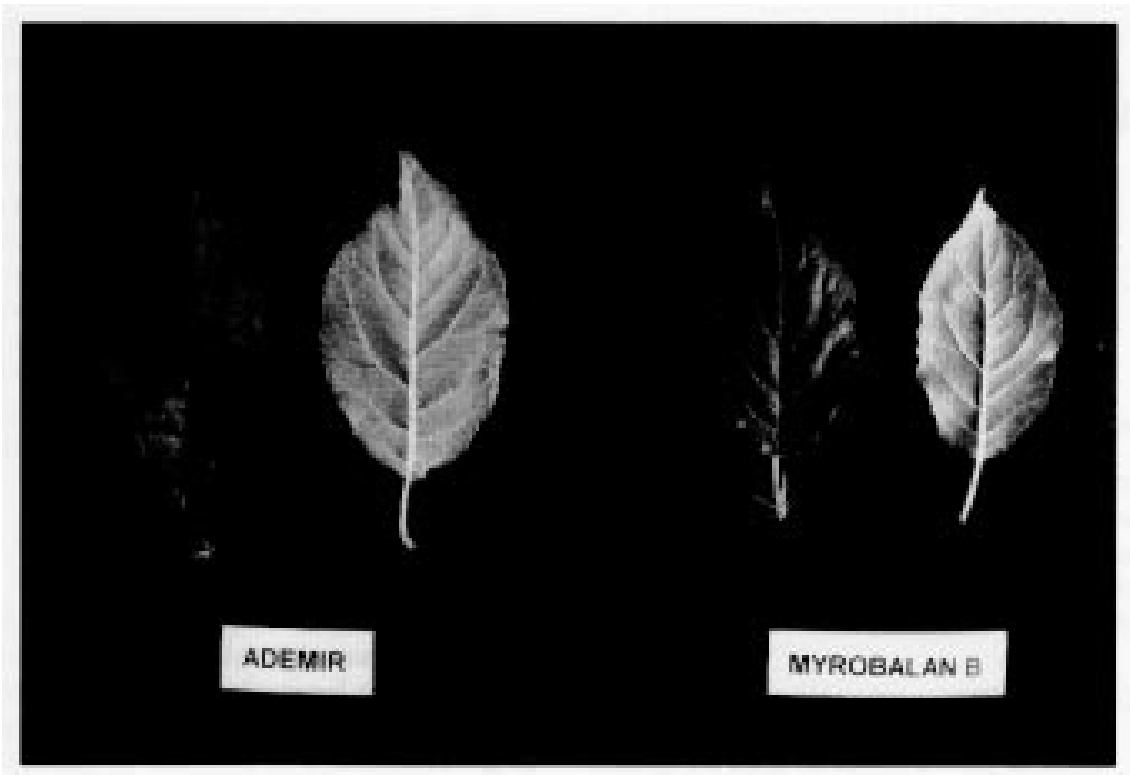

Fig. 1. Leaves (adaxial and abaxial sides) of Ademir and Myrobalan B rootstocks.

brown, and round-elliptical and asymmetric in shape in lateral view (length : breadth ratio $=$ $1.39 \pm 0.06$ ), and semi-globular in front view (length : width $=2.11 \pm 0.08$ ). The stone is small (length $=1.33 \pm 0.04 \mathrm{~cm}$ ), although slightly longer than that of Myrobalan B (length $=0.94 \pm 0.08 \mathrm{~cm})$.

\section{Availability}

\section{Literature Cited}

Cambra, R. 1979. Compatibilidad de variedades de albaricoquero con ciruelo Mirobolán (Prunus cerasifera Ehrh.) y Mariana (Prunus cerasifera Ehrh. x Prunus munsoniana Wight y Hedr.). Anales de la Estación Experimental de Aula Dei 14:371-375.

Cambra, R. 1990. El ciruelo Mirobolán Ademir como patrón de ciruelo y albaricoquero. Fruticultura Profesional 30:22-25.

Cambra, R. and M. Cambra. 1973. Selección clonal de ciruelo Mirobolán (Prunus cerasifera Ehrh.). Compatibilidad con variedades de ciruelo y albaricoquero. Anales de la Estación Experimental de Aula Dei 12:8-16.

Crossa-Raynaud, P. and J.M. Audergon. 1987. Apricot rootstocks, p. 295-320. In: R.C. Rom and R.F. Carlson (eds.). Rootstocks for fruit crops. Wiley, New York.

Duquesne, J. 1969. Etude de la compatibilité de greffe de quelques cultivars de Prunus armeniaca (Koehne) sur divers types de Prunus. I. Compatibilité des cultivars Canino et Rouge du Roussillon sur divers clones de Prunus cerasifera (Ehrh.) et hybrides interespécifiques. Ann. Amélior. Plantes 19:419-441.

Herrero, J. 1951. Studies of compatible and incompatible graft combinations with special reference to hardy fruit trees. J. Hort. Sci. 26:186-237.

Ademir registration is in progress. Small quantities of rooted cuttings or budwood can be obtained from the Estación Experimental de Aula Dei. Ademir is free of all known viruses (Moreno and R. Gella, unpublished).
Mosse, B. 1960. Graft incompatibility in plums; Observations on a ten-year-old field trial. J. Hort. Sci. 35:260-265.

Okie, W.R. 1987. Plum rootstocks, p. 321-360. In: R.C. Rom and R.F. Carlson (eds.). Rootstocks for fruit crops. Wiley, New York. 